\title{
Histochemical and immunohistochemical techniques in ulcerative colitis
}

\author{
*Hatim Alnuaimy **Noel Al-Sakkal \\ *Ai- Jamhori Teaching Hospital Mosul, **Department of pathology, Mosul College of Medicine, \\ University of Mosul.
}

(Ann. Coll. Med. Mosul 2008; 34(1): 28-34).

Received: $6^{\text {th }}$ Jun 2007; Accepted: $20^{\text {th }}$ Feb 2008.

\section{ABSTRACT}

Objective: To demonstrate the mucin changes in Ulcerative Colitis, to evaluate the benefit of the staining method and to demonstrate the CEA staining pattern in dysplasia complicating ulcerative colitis (U.C).

Methods: Colorectal biopsies were examined for changes of U.C for which a combined PAS/Alcian blue stain was applied. CEA immunohistochemical stain was used for cases of dysplasia complicating ulcerative colitis.

Results: One hundred colorectal biopsies were examined, U.C. was diagnosed in (22\%) of cases, the mean age was (36.68) years, (13) were males, and (9) were females. The prevalence of dysplastic changes complicating U.C were detected in $(22.7 \%)$. The rectum was the most frequent site of dysplasia complicating, U.C.. Two of the cases showed mild dysplastic changes; two showed moderate dysplasia, and only one showed severe dysplasia. The secretory activity of mucin in colorectal mucosa was tow in surface epithelium and varied in the crypts from absent or weak to moderate reduction.

The site of CEA distribution seemed to be affected mainly by degree of dysplasia, it was predominantly along the apical surface of the cells and also in the cytoplasm in case of mild dysplasia, while in moderate dysplasia it was of cytoplasmic distribution, and in severe dysplasia there was intensive cytoplasmic distribution.

Conclusion: There was an increase in relative frequency of U.C.

Immunohistochemical study of CEA localization in dysplastic gland is helpful in detection of early malignant change in U.C.

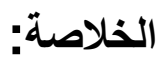

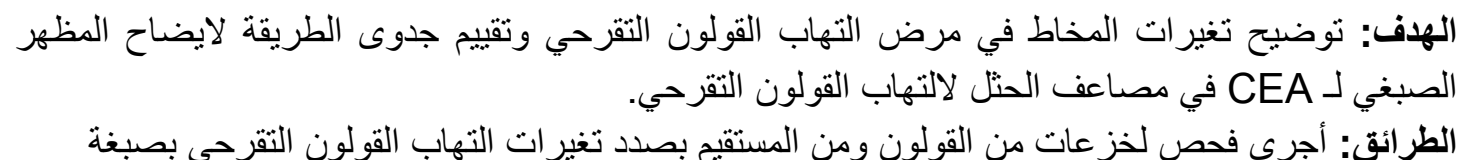


(PAS/Alcian) لالتهاب القولون التقرحي.

النتائج: أجري فحص مائة خزعة قولون او مستقيم، وشخص التهاب القولون التقرحي لاى بr \% من الحالات معدل

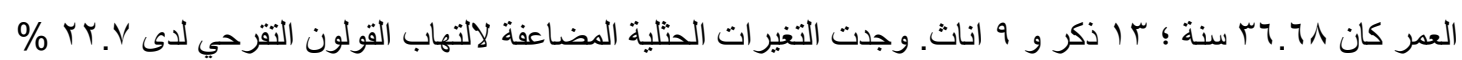

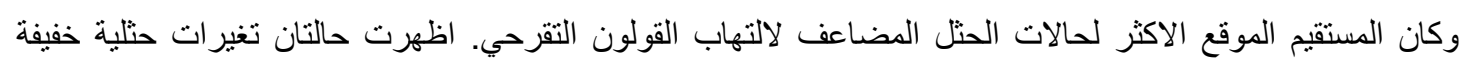
و اثتتان اخريان اظهرتا تغيرات حثلية منوسطة وواحدة فقط اظهر جرت تغير ات حتلية شديدة. كانت فعالية افراز المخاط

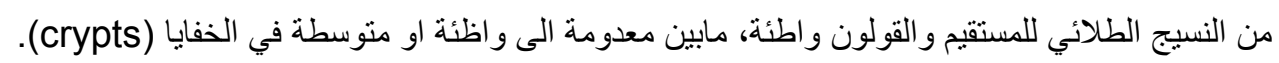
ويظهر ان موقع انتشار CEA يتأثر بدرجة الحثل، واكثر ما لوحظ في السطح القمي للخلايا وفي الهيولي في حالات الحتل الخفيف بينما كان منتشرا في الهيولي في الحالات المتوسطة وانتشار اشديدا لوطأة في الهيوليفي الحتل الثديد.

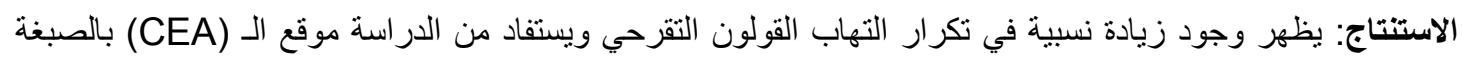

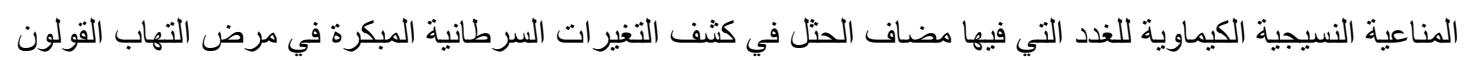
التقرحي.

U Icerative colitis is a chronic inflammatory disease of the rectum and colon ${ }^{(1,2-7)}$, and usually affects patients between (20-30) years, but may occur in younger and older individuals $(1,2,5,6,8,9)$. It is characteristically a left-sided disease that usually begins in the rectosigmoid area, in some cases it remains localized to the rectum (ulcerative proctitis), but in most instances, it spreads proximally and sometimes involves the entire colon (pancolitis) ${ }^{(6-8)}$.

Mucin changes in ulcerative colitis: In fulminant and acute active cases of short duration, the decrease in mucosubstance is slight or moderate, while in chronic active cases it is moderate or severe and these changes tend to revert again towards normal in quiescent phase ${ }^{(10)}$ Dysplasia: It is an unequivocally neoplastic but non-invasive epithelial proliferation of the colonic epithelium ${ }^{(11.12)}$.

Riddel et al. (1983) Classified dysplasia into ${ }^{(11)}$ :

1- Negative for dysplasia: which includes all inflammatory and regenerative lesions.

2- Indefinite for dysplasia; is applied to epithelial changes that appear to exceed the limits of ordinary regeneration.

3- Positive for dysplasia: which includes only cases with unequivocally neoplastic mucosa ${ }^{(11)}$.

4- Microscopically, dysplasia is identified on the basis of combination of microscopic features, which include; 
5-1- Architectural alteration exceeding that resulting from repair in chronic colitis.

2-Cytological abnormality principally cellular and nuclear pleomorphism, nuclear hyperchromatism, loss of nuclear polarity, mitosis, marked stratification of nuclei and variable mucin depletion ${ }^{(11,12)}$.

6-The distribution of CEA in normal epithelium is limited to the apical surface, while in dysplasia and carcinoma it is abundantly present in both cytoplasm and the lumen ${ }^{(8,13,14)}$.

Normally Colorectal goblet cells are containing mainly acid mucin with small amount of neutral mucin ${ }^{(15)}$. The composition of the goblet cell mucin varies within their level in the crypt and in different segments of colon; in the left colon sulphamucin predominates in the lower half of the crypt, whereas in the upper crypt and surface epithelium a variable proportion of sulphamucin and sialomucin are often demonstrated.

CEA is a glycoprotein of heterogeneous composition (MW 200,000), detected in small amounts in normal adult cells and benign colorectal tumors, but is present in large amounts in carcinoma ${ }^{(8)}$. The immunocytochemical localization of CEA in colorectal tissue may have a potential value in the diagnosis of premalignant and malignant lesions ${ }^{(14)}$.

\section{Patients and methods}

Colorectal biopsies were collected prospectively from (100) non selected patients with symptoms of large bowel disorders examined at the endoscopic units of AL-Jamhhori Teaching Hospital, AL-Salam Hospital, and private hospitals, in the period from October 2001 to July 2002. The age ranged from (2) months to (80) years. Medical history that included; age, sex and main presenting symptoms were recorded. All biopsies were fixed immediately in $(10 \%)$ formaldehyde for (24) hours, then the samples were processed routinely and embedded in paraffin blocks and stained with Haematoxylin and Eosin (H\&E) stain.

1. 1-A combined PAS-Alcian blue (pH.2.5) staining for neutral and acidic mucin were done respectively.

2. According to (Riddel et al., 1983) criteria (11). Immunohistochemical staining for CEA was performed in cases of U.C to detect dysplastic changes by using an improved Biotin- streptavidin Amplified (BSA) detection system. The staining procedure was done according to the manufacturer instructions of staining protocol ${ }^{(16)}$.

Statistical methods: The statistical evaluation was performed using mean, range, and chi square test.

\section{Results}

Ulcerative colitis was diagnosed in (22\%) of cases, in which different forms of disease activity were seen, table (1). The mean age was (36.68) years, ranging from (12 to 60) years, (13) were males, and (9) were females, tables $(2,3)$. The prevalence of dysplastic changes complicating U.C were detected in $(22.7 \%)$ with mean age (41.8) years ranging from (29 to 60 ) years, three of them were females and two of 
them were males, table (3). The sex distribution was statistically insignificant. The rectum was the most frequent site showing dysplasia complicating, U.C. 3/5 compared to other sites. Two of the cases showed mild dysplastic changes; two with moderate dysplasia, and only one had severe dysplasia, table (4).

Mucin changes in U.C: The result of PAS/Alcian blue techniques for the demonstration of mucin, failed to detect any qualitative difference in reactivity in U.C. The secretory activity in colorectal mucosa was diminished in surface epithelium and varied in the crypts from absent or weak to moderate reduction, table(1).

Distribution of CEA immunohistochemical staining in dysplasia complicating U.C: In mild dysplasia, CEA distribution was demonstrated predominantly along the apical surface of the cells, while in moderate dysplasia and in severe dysplasia there was intensive cytoplasmic staining.

Table 1: Mucin chanaes in U.C. and dysnlasia.

\begin{tabular}{|c|c|c|c|c|c|c|c|}
\hline \multirow{4}{*}{$\begin{array}{l}\text { Pathological } \\
\text { Diagnosis of U.C. }\end{array}$} & \multirow{4}{*}{$\begin{array}{l}\text { No of } \\
\text { cases }\end{array}$} & \multicolumn{3}{|c|}{ PAS } & \multicolumn{3}{|c|}{ Alcian blue } \\
\hline & & \multicolumn{3}{|c|}{ score } & \multicolumn{3}{|c|}{ score } \\
\hline & & 3 & 2 & 1 & 3 & 2 & 1 \\
\hline & & ++ & + & \pm & ++ & + & \pm \\
\hline Active & 10 & 1 & 3 & 6 & 0 & 2 & 8 \\
\hline Inactive & 7 & 1 & 3 & 3 & 1 & 2 & 4 \\
\hline \multirow{3}{*}{$\begin{aligned} \text { Dysplasia: . mild } \\
\text {. Moderate } \\
\text {. Severe }\end{aligned}$} & 2 & & 1 & 1 & & 1 & 1 \\
\hline & 2 & & 1 & 1 & & & 2 \\
\hline & 1 & & & 1 & & & 1 \\
\hline Total & 22 & 2 & 8 & 12 & 1 & 5 & 16 \\
\hline
\end{tabular}

Table 2: Sex distribution of U.C. with and without dysplasia.

\begin{tabular}{|c|c|c|c|}
\hline \multirow{2}{*}{ sex } & \multicolumn{2}{|c|}{ Ulcerative colitis } & \multirow{2}{*}{ Total } \\
\cline { 2 - 4 } & With dysplasia & Without dysplasia & 13 \\
\hline Male & 2 & 11 & 9 \\
\hline Female & 3 & 6 & 22 \\
\hline total & 5 & 17 & 17 \\
\hline
\end{tabular}

( $P$ value using Chi-square test $=0.323$ ). copic findings in U.C with dysplasia. 
Table 3:

\begin{tabular}{|c|l|l|l|l|c|}
\hline $\begin{array}{c}\text { Age } \\
\text { (Year) }\end{array}$ & Sex & Site & Endoscopy & Symptom & Grade \\
\hline 29 & Female & $\begin{array}{c}\text { Descending } \\
\text { colon }\end{array}$ & Ulceration & Blooding per rectum & Mild \\
\hline 31 & Female & Rectum & Thickening & Bleeding per rectum & Moderato \\
\hline 38 & Male & Sigmold & Polyp & Bleeding per rectum & Moderate \\
\hline 50 & Female & Rectum & Ulceration & Blooding per rectum & Mild \\
\hline 60 & Male & Rectum & Ulceration & Bleeding per rectum & Severe \\
\hline
\end{tabular}

Table 4: Predominance of CEA distribution in colonic biopsies of U.C with dysplasia

\begin{tabular}{|c|c|c|c|}
\hline Grade & Apical & Cytoplasmic & Basolateral \\
\hline Mild & + & \pm & - \\
\hline Moderate & + & + & - \\
\hline Severe & + & + & + \\
\hline
\end{tabular}

\section{Discussion}

Ulcerative colitis constituted (22\%) of the cases, which is higher than (18\%) reported by Saadi $(1989)^{(18)}$. This may be due to:

1. wider use of sigmoidoscopy.

2. our physicians now have high index of suspicion for U.C.

In Europe and North America, higher figures were also reported $(36 \%)^{(5,19)}$.

The age ranged from (22 to 64) years with peak age distribution at $3^{\text {rd }}$ decade, this more or less is similar to the studies of others $(15-25)^{(19,20,21)}$. Some reported higher figures(38.1)years ${ }^{(22,23)}$. Regarding sex distribution, males were affected more than females, while (Al-Nakib et al, 1984) found a nearly equal sex distribution $(\mathrm{F} / \mathrm{M}=21 / 22)^{(2)}$.

\section{Mucin Pattern in U.C.}

The study of mucin pattern in U.C. showed that, both types of mucin were detected but in decreased amount indicating that, the change in mucin is quantitative rather than qualitative; this finding is similar to that observed by Nazar ${ }^{(24)}$. The amount of mucin decreased when the activity of disease is increased, this observation is in agreement with other workers ${ }^{(25,26,27)}$. In our study, all types of mucin present in an inactive colitis were higher in amount than that found in active colitis, this is consistent with observations of other workers ${ }^{(28,29)}$

Special attention has been focused on pre-carcinomatous changes (dysplasia) in patients with U.C. which is considered as a histological marker for increased cancer risk, and thus, as a potential indication for colectomy in patients with U.C. In the present study, (22.7\%) of cases of U.C. had dysplastic changes and this is more or less similar to the some studies (21 $\%)^{(12,30)}$, and higher than that reported, by (Katran), and (Subbar), (14.7) and (6.5) 
respectively ${ }^{(25,31)}$.

The frequency of the grade of dysplasia was $(40 \%)$ mild dysplasia, (40\%) moderate dysplasia, while severe dysplasia constituted (20\%). These figures are more or less similar to those studies $(18 \% \text { mild, } 35 \% \text { moderate, } 47 \% \text { severe })^{(25,}$ $32,33)$

Statistically, it was found that there was no significant relationship between dysplasia complicating U.C. and sex distribution, which is in agreement with another study done by (Katran, 2001$)^{(25)}$.

\section{CEA Immunohistochemical Study:}

We found a good correlation of CEA localization and Severity of dysplasia; this also was observed by others ${ }^{(17,25)}$. So this marker is considered as reliable indicator for pre-malignant changes in U.C.

\section{References}

1. Roddie M.N., Macsween, Keith Whaley, Muirs Textbook of pathology, $13^{\text {th }}$ ed., EIBS, 1994: 704-736.

2. Chosh S., Shand A., and Ferguson A., Regular review; Ulcerative colitis, BMJ 2000; 320: 1119-1123.

3. Brandtzaeg PER. "Autoimmunity and U.C.: Can two enigmas make sense together?, Gastroenterology, 1995; 109: 307-322.

4.Pullan RD, Thoma, GA, Rhodes M., et_al. Thickness of adherent mucous gel on colon mucosa in humans and its relevance to colitis. Gut 1994:35:353-359

5.Clenum M, Eisen, Roberts, Epidemiology and I.B.D., CCFA (Crohn's and Colitis foundation of America) (2002). (Available from: URL: http: // www. ccfa. org / Medcentral / research / clinical).
6. NDDIC, (National digestive disease information clearing house), April 2000. (Available from: URL: nttp://www hiddk.nih.gov/health/digest/pubs/colitis.htm ,\# symptoms).

7. Nagama Inoue, Watanabe M., Sato T:, et al., Restricted VH Gene usage in lamina propria $B$ cells producing anticolon antibody from patient with U.C., Gastroentrology, 2001; 121: 15-23.

8. Rosai J. Ackerman's surgical pathology, $8^{\text {th }}$ ed. Vol. $1^{\text {st }}$.Louis, Mosby, 1996:729-781.

9. Kumar V., Cotran R, Robbins, Robbins Pathologic basis of disease, $6^{\text {th }}$ ed., W. B. Saunders Company, 1999; 802: 840.

10.Fillip, E. M.I., and Dawson I., The diagnostic value of mucou-substance in rectal biopsies from patients with U.C.and Crohn's disease, Gut, 1970;11:229-234.

11.Riddel R.H., Goldman H., Ransohoff D.F., et al., Dysplasia in I.B.D. standardized classification with provisional clinical application Human pathology 1983 ; 14(11) : 931-966.

12.Ransohoff D., Riddell R.H., Leven B., Ulcerative colitis and colonic cancer problems in assessing the diagnostic usefulness of mucosal dysplasia, Disease of colon and rectum 1985; 28, (6): 383-388.

13.Stevens A. Human histology, $2^{\text {nd }}$ ed., London, Mosby1997: 208-214.

14.Michael J. Zamc;heck. N. Burke B. et al. Immunocytochemical localization of CEA in benign and malignant colorectal tissue, assessment of diagnostic value. A.J.C.P; 1981: 75 (3): 283-289.

15.Sugihara K., Jass J.R., and Colorectal 
goblet cell sialomucin heterogeneity: its relation to malignant disease. J. clin. Pathol. 1986; 39: 1088-1095.

16. Kit.

17.Hamada Y., Yamamura M., Hioki K., immune histochemical study of CEA in patient with colorectal cancer correlation with plasma CEA levels, cancer 1985; 55 (1): 136-141.

18.Saadi, R., The role of mucosal biopsy in the diagnosis of large bowel disease, [thesis] 1989. Department of Pathology, College of Medicine, University of Mosul.

19.Rousseau G, Salmomez J; Dupas J et al. Incidence of inflammatory bowel disease in North France (1988-1990), Gut, 1994;35:1433-1438.

20.Falogan R., Inflammatory Bowel disease incidence: up, down or unchanged?, Gut 1998; 42: 309-311.

21.Al-Nakib B., Radhakrishnan S., Jacob G.S.; et al., Inflammatory bowel disease in Kuwait; American Journal of Gastroenterology 1984; 79 (30): 191-194.

22.Wheats P.R. Buski H. HG, Daniels U.G. , Functional Histology, A text and color atlas. Churchill living stone, 1987:203-224

23. Edwards CM, Gerorge B and Warren B, Diversion colitis - new light through old windows, Histopathology, 1999; 34, 1-5.

24.Nazar G., "The changes of the types of colonic mucin in the inflammatory and neoplastic colonic lesions, [Thesis] 1998. Department of Pathology, College of Medicine, University of Baghdad.

\section{Katran M., "Histopathological,} Histochemical and immuno histochemical studies of dysplasia and cancer complicating U.C. [Thesis] 2001. Department of Pathology, College of Medicine, University of Baghdad.

26.Agawa S., Muty T., Morroka Y., Mucin abnormality of colonic mucosa in U.C. Dis. Colon rectum 1988;387-389.

27.Ahnen D. J, Warres G., Green L. J., Search for a specific marker of mucosal dysplasia in chronic U.C., Gastroenterology 1989; 93: 1346-1355.

28.Allen D. C., Cannolly N. S., Biggart J. D., Mucin profile in U.C. in dysplasia and cancer, Histbpathology 1986;13: 413-424.

29.Jass J. R., England J, Millerk, Value of mucin in follow up surveillance of patient with longstanding U.C.J. Clin. Path, 1986; 39: 393-396.

30.Dickinson R.J. Dixor. M.F., Axon A.LR. Colonoscopy and the detection of dysplasia in patients with longstanding U.C. The lancent, 1980; 20: 620-621.

31.Subbar A, Rhagad K. Spectrum of colitis, [Thesis] 2000 GIT center College of Medicine, Baghdad University.

32.Woolrich AJ, Dasilva MD, Korelitz BI, Surveillance in routine management of U.C. in the predictive value of low grade dysplasia Gastroentrology, 1992; 103(2): 431-8. (Cited by).

33.Suskin K, Muto J, Agawa S, Nippen S, Cakkai Z. Dysplasia in U.C. detected by surveillance colonoscopy 1991: 28 (4): 1051-9 (Abstract). 